\title{
JUDGING GOOD APPEARANCE IN PERSONNEL SELECTION
}

\author{
0 julgamento da boa aparência em seleção de pessoal
}

\author{
Altair dos Santos Paim* \\ Marcos Emanoel Pereira**
}

\begin{abstract}
Judgement of what one views as good appearance in the selection of job applicants may reveal racial bias in access to the labor market. The purpose of this study is to evaluate the effects of racism in judging physical appearance in personnel selection. The non-random sample was composed of seventy-four (74) participants, of whom forty-two were human resources professionals (57\%). The instruments used were an assessment of résumés, a set of prejudice scales, an inventory of racism in the labor market, an indicator of good appearance and a sociodemographic questionnaire. Three hypotheses were tested. Hypothesis 1 , which postulated a preference for white candidates was confirmed. Hypothesis 2 was corroborated, because the professionals showed a higher tendency to choose candidates with a fairer complexion. Hypothesis 3 , which made reference to good appearance was rejected, because the participants elected hygiene as a further element present in the judgment in selecting candidates. Finally, it is considered that the selection process should be based on the acceptance of racial diversity, a key element for the development of creative and innovative organizations.
\end{abstract}

Keywords: Social Psychology. Racism. Good looks. Personnel Selection.

\section{RESUMO}

A boa aparência nos processos seletivos pode revelar o viés racial no acesso ao mercado de trabalho. Este estudo teve como objetivo avaliar os efeitos do racismo no julgamento da boa aparência em seleção de pessoal. A amostra, não aleatória, foi composta por setenta e quatro (74) participantes, sendo quarenta e dois profissionais (57\%). Os instrumentos utilizados foram uma avaliação de currículos, um conjunto de escalas de preconceitos, um inventário sobre racismo no mercado de trabalho, um indicador de boa aparência e um questionário sociodemográfico. Três hipóteses foram testadas. A hipótese 1 que postulava a preferência por candidatos brancos foi confirmada. A hipótese 2 foi corroborada, pois os profissionais mostraram uma maior tendência em escolher candidatos de cor mais clara. A hipótese 3 referente à boa aparência foi rejeitada, pois os participantes elegeram a higiene como um elemento mais presente no julgamento em seleção de candidatos. Considera-se por fim que os processos seletivos devem se fundamentar no acolhimento da diversidade racial, elemento fundamental para o desenvolvimento criativo e inovador das organizações.

Palavras-chave: Psicologia Social. Racismo. Boa Aparência. Seleção de Pessoal.

\footnotetext{
* Professor do Instituto Federal de Educação e Ciência Tecnológica da Bahia. Doutor em Psicologia pela Universidade Federal da Bahia (UFBA). E-mail: altairpaim@ifba.edu.br. ORCID: 0000-0003-4996-9763

** Professor do Programa de Pós-graduação em Psicologia no Instituto de Psicologia da Universidade Federal da Bahia (UFBA). Doutor em Psicologia pela Universidade Federal do Rio de Janeiro (UFRJ). E-mail: memanoel@ gmail.com. ORCID: 0000-0001-7613-6893
} 


\section{INTRODUCTION}

$\mathrm{P}$ ersonnel selection represents the process used for hiring qualified professionals to meet the needs pointed out by several sectors of an organization. In order to be efficient, it is essential that the previous stage, screening/shortlisting, be performed in an adequate and consistent way (MAZON; TREVIZAN, 2000). From the candidates recruited, the person selecting the applicants evaluates the most suitable candidates for the position, and, to do so, must use objective criteria such as education, skills, knowledge and professional experience.

This process, however, is not free from stereotypes and social prejudices. Shared beliefs and representations guide practices and distort the perception of the recruiter in the process of comparing candidates. A choice that should be made on the basis of competencies for professional performance may suffer the effect of biased judgment based on assumed and stereotyped attributes. The recruiter's bias can guide strategies for recruiting and selecting people for the organization. The professional is confronted with the information overload associated with the number of candidates and the dynamics of the interactions in the various stages of the selection process. In this context, they can reproduce cultural stereotypes to minimize uncertainties, simplify and justify their decisions (UHLMANN; SILBERZAHN, 2014).

The expression has been perceived by the black movement as a subtle mechanism of institutional racism that operates constant and regular practices of racial discrimination in organizations. (FIGUEIREDO, 1994; PAIM, 2005; DAMASCENO, 2011). Damasceno (2011) investigated, in Rio de Janeiro's newspaper ads from the 1930s to the mid-1950s, the meanings of this requirement for domestic work. The association between the term and skin color of the candidates was explicit in advertisements until the mid-1940s. From the 1950 s on, the expression was restricted to functions that were more valued socially. This phenomenon demonstrated the blatant exclusion mechanism of a society that only four decades before had gotten rid of slavery and did not have any type of legislation to combat racism. In the master's dissertation, "Physical appearance, stereotypes and professional insertion: a study on the profession of executive secretary according to the students' perception" (Aparência física, estereótipos e inserção profissional: um estudo sobre a profissão de secretariado executivo segundo a percepção das estudantes de secretariado) the object of study was the judgment on good looks (PAIM, 2005) among students of Executive Secretary programs, in two colleges, a public and a private institution. The hypothesis that such a criterion is fundamental to be a secretary was attested, and the students who participated in the study acknowledged the existence of racial discrimination practices in this professional space in the city of Salvador.

In some Brazilian states and cities, regulations have been created aiming to avoid this discriminatory process. Law 1905 of 11/24/98, in Mato Grosso do Sul, and Law $5876 / 2015$, in the State of Rio de Janeiro, are examples of norms that prohibit the use of the expression good appearance in any job advertisement. Gomes, Braga, and Vieira (2008) in their survey of job ads in a major newspaper in the Federal District noted a warning that advertisers do not include requirements considered discriminatory. 
In Salvador, specifically, the Public Prosecutor's Office and the major newspapers made an agreement, in 1992, so that advertisements with such a requirement would no longer be published. Law 5.420, published on September 4, 1998, specifies the prohibition of such expression in advertisements of employment, in the capital of Bahia, providing for the punishment of those who fail to comply.

The judgment of physical attributes in human resources (HR) practices reveals how current racism combines flagrant and subtle forms of expression that circumvent the anti-racist norm in democratic societies (LIMA et al., 2006; PEREIRA; VALA, 2011). The newspaper job advertisements in the capital of Bahia no longer have any explicit demands regarding the appearance of a candidate for different job openings. Nevertheless, the recruiters still ground their choices on this criterion (PAIM, 2005).

A gap on the criteria that determine the requirement of good looks remains. The present article is a research report that sought to answer specific questions about these criteria in personnel selection and to what extent racist beliefs determine the process of screening. The purpose of the research was to evaluate the effect of the candidate's racial categorization on the selection of personnel. In order to do so, the following specific objectives were defined: comparing the judgments on black and white candidates for external (direct contact with the client) and internal (no client contact) functions; checking the criteria used to determine the good appearance of a jobseeker; and evaluating the effect of racial prejudice on the selection of candidates in personnel selection. To achieve the objectives, a simulated selection of résumés was carried out with the participation of human resources professionals and undergraduate students.

\section{STEREOTYPES AND RACIAL PREUUDICE IN THE LABOR MARKET}

The perception of physical appearance is fundamental for the process of categorization and, therefore, for the creation and development of stereotypes. Appearance facilitates the maintenance of labels attributed to a group, as it allows the perceiver to distinguish and homogenize the members of a target group under judgment. Stereotypes are embedded in the culture in which they are shared and are reproduced throughout all social structures (BROWN, 2010), being transmitted through socialization, in the family and at school, in repeated exposure to images in books, television, newspapers and the media in general (BAR-TAL, 1997; BROWN, 2010). These stereotyped beliefs represent a particular constellation of features and functions associated with a group (DOVIDIO; HEBL, 2005; JUSSIM et al., 2009) and serve as the foundation for judgments based on the supposedly shared attributes (BIERNAT, 2009), creating a context of expectations against which an individual member of the group is assessed.

Biernat, Fuegen and Kobrynowicz (2010) evaluated how stereotypes of work-related incompetence affect the hiring process of the applicant. This happens when people judge an individual member of a stereotyped group and might use a stereotyped expectation as a standard or reference point. Such expectation, influenced by the stereotype then lowers the standards in relation to certain attributes when members of excluded groups are evaluated. Stereotyped beliefs are at the basis of biased attitudes. 
Prejudice, as other attitudes, provides an outline for interpreting the environment, and preparing people to make decisions (DOVIDIO; HEBL, 2005) supporting discriminatory behaviors (PEREIRA, 2002; BROWN, 2010), such as maintaining and justifying hegemonic hierarchies of power and status and social invisibility that makes the group become under-represented (FRYBERG; TOWNSEND, 2008). Racial discrimination usually is the expression of an attitudinal structure that is produced in a society marked by inequalities between groups.

Race, in this study, is understood not as a biological condition, but as a construction erected in sociocultural relations (GUIMARÃES, 2003), since racial interactions are structured as a function of group disputes over power, status and social space. Guimarães (2004) emphasizes that the adoption of a mistaken view of human biology, expressed by the concept of "race", established a justification for the subordination of other individuals and peoples. The nineteenth-century scientific ideology, expressed in Biology and Law, transformed a temporary inequality (cultural, social and political), into a permanent, biological inequality (GUIMARÃES, 2003).

The works of Pager, Western and Bonikowski (2009), Pager and Western (2012) allow us to reflect on the discriminatory behavior in personnel selection. In their research, individuals who differ only by their race or ethnicity were trained and rigorously chosen to apply for real job openings. In the studies, men between the ages of 21 and 24 were hired to play the role of job seekers. These young people (testers) were matched based on their physical characteristics (height, weight, attractiveness), verbal skills, interaction styles (eye contact level, behavior, and verbosity), educational attainment, work experience (quantity and type) and neighborhood of residence. The dependent variable in each study would be any positive response in which a job was offered or they were called back for a second interview. The rate of positive responses for white candidates was up to twice as high as the rate observed for equally qualified black candidates. In most of the selections, participants did not detect signs that employers would anticipate a different treatment, but the white candidate was chosen for the job.

Rooth (2010) conducted an experiment to evaluate discrimination against (Arab) minorities in personnel selection. Two different field experiments on ethnic discrimination in hiring personnel were combined with a measure of automatic attitudes of recruiters and performance stereotypes toward Arab and Muslim men compared to Swedish men using the Implicit Association Test (IAT). The results showed how negative attitudes toward Arabs and Muslims can predict discrimination in selection processes. These conclusions are in line with the discussions of Bendick Jr. and Nunes (2012) who have studied how the effect of negative associations on selection processes affects socially excluded groups such as blacks, who are perceived as uneducated, and women, who are viewed as not being committed to the professional career.

Harrison and Thomas (2009) analyze the influence of "skin tone" or colorism on racial discrimination in the labor market, arguing that most studies fail to recognize the role of skin-tone stratification. Therefore, they created an experiment in which the participants should evaluate résumés which contained one of the three photos of the same black candidate (there were three photos of the same man and three photos of the same woman with skins with various color shades, that is, with a dark, medium and light skin tone). Partici- 
pants evaluated the candidate based on academic background, previous work experience and general curriculum. The participants then received six image options and indicated the one that had appeared in the résumé they had read. The results suggest that skin tone plays a considerable and more prominent role than the educational background and prior work experience: there was a preference for candidates with a lighter skin tone.

Brown-lannuzzi, Payne and Trawalter (2012) conducted two experiments on racial discrimination in selective processes. Participants in the experimental condition were asked to imagine an ideal employee for a skilled job in a company. The authors used a measure of prejudice to identify the effect of negative attitudes on choice. The hypothesis that people could bias the judgment in favor of white candidates was corroborated and this occurred independently of explicit prejudice, suggesting that even less prejudiced individuals may be affected by this bias.

A racist society spreads negative stereotypes about racial groups (bad hair $\mathrm{x}$ straight hair, a black person with a white soul, dirty belly $x$ clean belly) that resonate in all spheres of social institutions. Stereotypes reinforce negative feelings that define social distance and preferences in the daily life of Brazilian society. Racism is based on prejudiced feelings, stereotyped thoughts of individuals who are biased and prone to discriminatory actions. Racism and other forms of oppression consist not only of obstacles that unjustly prevent the inclusion of people who are members of oppressed groups, but it is also present in the creation of a system of privileges for people belonging to dominant groups.

Dovidio, Gaertner, and Kawakami (2013) consider that racism represents an organized system of exclusion that is systematically structured on the basis of disadvantages for a group because they are members of a certain race. For the authors, there would be three defining elements of racism. First, it reflects a culturally shared belief that groups have physical characteristics that are common to their members and distinguish them from other groups. Second, some physical characteristics renders one group as inferior to others. Third, racism involves not only negative beliefs and attitudes, but also social disadvantages and limited opportunities.

Attributes such as beauty, competence and intelligence would supposedly be shared according to the perceived race. This phenomenon does not derive, but is associated with the socioeconomic structure of the country that segregated the black population from opportunities for upward mobility and condemned them to negative indexes of social inclusion. Racism is distinguished from prejudice because it is a historical product that, in its structure, presents "the naturalization of differences, the hierarchization of cultures, and consequent infra-humanization of racialized minorities, as well as the ideological function of justifying the social and economic position of the groups which are the targets of discrimination". (LIMA, 2005, p.85).

Contemporary racism is characterized by being indirect and wrapped with imprecision and uncertainty (LIMA; VALA, 2004; NUNES, 2010). In the literature, the expressions of subtle racism receive different denominations such as Symbolic, Modern, Ambivalent, Aversive and Subtle Racism (LIMA, 2004, AUGOUSTINOS; WALKER, 2006). In their research, Camino et al. (2001) discussed the reduction of explicit acts of racial discrimination in Brazil. Facing laws that prohibit such practice, people have started inhibiting the expression of prejudice, while retaining negative attitudes. Nunes (2010), in a doctoral thesis, 
investigated the phenomenon. The study was conducted to evaluate prejudice against blacks in Brazil, as well as to analyze negative attitudes toward gypsies in Spain. The research used open interviews and scales of subtle and flagrant racism. The results demonstrate how flagrant racism has less expression in both countries. The subtlety of racism came in the form of racist jokes, blaming the blacks and the gypsies for their disadvantage. In addition, participants asserted that black people should be responsible for changing their situation, and thereby refuse the proposals of racial public policies such as affirmative action.

In opposition, direct and declared forms of racial hierarchy are perceived (ZÁRATE, 2009). Racist insults on social networks, offenses with the same content in sports competitions and discourses against affirmative action policies reinforce this theory. Brazilian racism was structured, among other forms, on the basis of explicit disqualification of the physical appearance of the black population. Skin color, hair texture, nose and lip shape were the main targets of stereotyped images. The judgment on white aesthetics (straight hair, fair skin and narrow nose) would be positive and, therefore, the pattern to be followed by other racial groups.

The labor market is an essential context for analyzing this phenomenon, since racism is shown explicitly in this space. People need to conform to the social norms demanded, whether implicit or not, according to expectations of behavior that are reinforced in organizations. By electing physical attractiveness as a criterion, the personnel recruiter would define the hiring of personnel on the basis of an aesthetic standard (SALGUEIRO, 2009) that must be socially imposed. In this case, professional experience is often neglected for the benefit of an attribute that is more related to the physical attractiveness of the candidate, and, consequently, attractive faces are favored in decision making in personnel selection (HOSODA; STONE; STONE-ROMERO, 2003; SHAHANI-DENNING, 2003; HARRISON; THOMAS, 2009; LITTLE, 2012).

In order to understand decision-making in the selection of people on the basis of race, it is essential to discuss how the perception of a candidate's racial belonging is configured. Racial belonging depends on the subject's position, target or picker. In the case of the recruiter, it is subject to the acceptance of the racial condition and the perception that the subject constructs about that social group. The target (candidate) undergoes an evaluation of their physical appearance in the sense of being identified as belonging to a racial group. The recruiter can fit the candidate into a racial category (black, white, brown, indigenous) regardless of self-perceived phenotypic characteristics. An individual with a darker skin tone may perceive her/himself as not being black because s/he has straight or wavy hair. The evaluator, however, can define her/him as being black. That means that a person may have a lighter skin tone and be perceived as black. Social judgment about physical appearance refers to the color, skin tone and hair type of the individual being evaluated.

Racial belonging, perceived under the filters of prejudice, restricts the candidates perceived as white to the vacancies that are destined to direct customer service or in a prestigious organizational position. In a selection context, the perceived physical appearance reinforces the stereotypes that hold expectations about the members of a target group (MOURA; LOPES, 2014). The interviewer associates stereotyped beliefs with the characteristics established by the work and makes a biased decision in favor of a candidate who represents the ideal professional expected for the position. Studies on racial bias in staff selection have 
shown how the perception about skin color can determine restricted spaces in the access to the labor market (BROWN-IANNUZZI; PAYNE; TRAWALTER, 2012; MOURA; LOPES, 2014).

\section{HYPOTHESES}

Hypothesis 1 postulates that participants preferably choose white candidates in personnel selection. The decision-making in this sense (SHAHANI-DENNING, 2003; AGTHE et al., 2014) is influenced by stereotyped beliefs and expectations about the physical appearance of the target candidate (LANGLOIS et al., 2000). Hypothesis 2 indicates that, unlike the choice pattern of the students, HR professionals tend to make choices yielding to the racist norm. The labor market pressures those responsible for selecting personnel in their organizations to choose a candidate to fill a position (LANGLOIS et al., 2000; SHAHANI-DENNING, 2003; AGTHE et al., 2014), influenced by stereotypes. Hypothesis 3, regarding good appearance, supposes that in the judgment on the items that define this criterion in a selection of personnel, the color of the skin would present a lower rate of acceptance, as participants tend to control prejudice by denying that skin color defines 'good appearance' or physical attractiveness.

\section{METHODOLOGY}

\section{PARTICIPANTS}

The non-random sample consisted of seventy-four (74) participants; forty-two were professionals (57\%) from the Human Resources area. The participants declared themselves mostly female (77\%), black (41\%) and brown (23\%); and their age ranged from 19 to 56 years $(M=29 ; S D=7.75)$.

\section{INSTRUMENTS}

A software was built to make it easier for participants to simulate a selection of résumés in two conditions, with a photograph or without a photograph. The résumés were constructed based on the template ${ }^{1}$, and changes were adopted based on the suggestion of two consultants, one with a master's degree in organizational psychology and a personnel management consultant.

The photos were taken from the prototypical image database developed by Mendes, Arrais and Fukusima (2009), and submitted to validation by judges. A scale was then produced with the following formatting: at one end was the prototypical image of the darker man, who was given the value one (1) and, at the other extreme, the most prototypical picture of a white, which received the value eight (8). The other photographs represented

1. Available on <http://office.microsoft.com/en-us/templates/curriculo-TC102918880.aspx>. 
black men according to a gradient of fairer skin $(2,3,4)$ and white men with a skin tone that was a little darker $(5,6,7)$, representing an ascending scale of skin tone evaluation. The positions of salesperson (direct contact with the client) and typist were chosen for the recruitment simulation.

To maintain the standardization, an advertisement that was found in a newspaper of great circulation in Salvador was choses, because it met the specifications for the seller and typist positions. This advertisement was adjustable for candidates in both areas, as it presented only three explicit requirements: high school degree, the requirement of good looks and property of a vehicle. The requirement for good appearance was excluded from the advertisement to avoid the influence of social desirability on participants' responses and to identify to what extent this criterion still persists in the evaluation of candidates in personnel selection. Five human resource professionals evaluated the software by identifying inadequacies and flaws.

\section{PROCEDURE}

The participant, after having read and accepted the Informed Consent Term, evaluated three résumés according to the advertisement presented for the seller position, in accordance with five criteria: professional experience, training and personal development, academic background and professional profile; then they would choose the most suitable candidate for the position. Three résumés for the typist position were also analyzed under the same criteria.

In the photo condition, the software randomly adjusted the résumé and photo for evaluation of the participants, so that everyone had the same chance to evaluate all the photos of the scale. In the no-photo condition, the résumé was presented with a silhouette of the image.

After the evaluation of the résumé, the participants answered a set of five-point scales, with the following extremes: I totally disagree (1) and totally agree (5), namely: Motivation Scale to Respond Without Prejudice (GOUVEIA et al., 1998), Scale of Racial Privilege (NEVILLE et al., 2000), Scale of Flagrant Racism (NEVILLE et al., 2000) and Scale of Affirmation of Differences (SANTOS et al., 2006). The participants also completed an Inventory on Racism on the Labor Market, based on the reflections and discussions proposed by Pereira (2015) on racial discrimination, with choices of responses (1) yes or (2) no, an indicator of good appearance and a sociodemographic data questionnaire (PAIM, 2016).

In view of the Resolution 466/2012 of the National Health Council, which assists the rights and duties that concern the scientific community, research subjects and the State, this study was conducted according to the ethical principles present in the scenario of research with human beings

All data collection was performed on a Pentium 200 Mhz notebook, running the Windows XP operating system. The instruments used were an evaluation of résumés, a set of biases, an inventory of racism in the labor market, an indicator of good appearance and a sociodemographic questionnaire. The instruments were elaborated with the Asymetrix Toolbook Instructor II, version 5.03. 


\title{
DATA ANALYSIS AND DISCUSSION
}

\author{
JUDGMENT ON APPEARANCE
}

The hypothesis regarding appearance indicated that participants in the condition with photo, on average, would preferably choose candidates with a lighter skin color. The data confirmed the hypothesis. In the evaluation of résumés for the position of seller, the white candidates presented a greater percentage of choices in all the items, with or without the presence of a résumé with the photo of a black candidate. The résumés that presented the white prototypical photo obtained a greater percentage of choices regarding the profile $(60 \%)$, professional training (54\%), experience (58\%) and courses (52\%). Résumés with prototypical photographs of blacks received a higher percentage of choices in items judged for the typist advertisement: academic background (61\%), experience $(60 \%)$ courses $(57 \%)$ profile (57\%).

In order to evaluate the effect of the skin tone criterion in the evaluation of the photos for the seller and typist résumés, we conducted two t-tests for a single sample. In both, the value 4 was adopted (corresponding to the black candidate's measure with less prototypical characteristics). In the case of the seller, a significant difference was identified in relation to the test value (Mean $(M)=5.0$, Standard Deviation $(S D)=2.45, t_{(35)}=2.45$ $p<.05)$, which did not happen in the case of the typist $\left(M=4.6, S D=2.29, t_{(35)}=1.53\right.$ $\mathrm{p}=.135)$.

Shahani-Denning (2003) reflects how the presence of photos in a résumé influences the choice of the most attractive candidate for this position. The seller position demands, in principle, direct contact with the public. The recruiter directs their choice, guiding themselves by an image which is deemed appropriate to a supposedly standard of attractiveness for this job. This ideal image for a candidate, a professional with a fairer complexion, determines the decision making process, biasing the judgment in favor of a candidate who meets the expectations of physical attractiveness (BROWN-IANNUZZI; PAYNE; TRAWALTER, 2012; MOURA; LOPES, 2014). When using this parameter for the choice, the recruiter combines stereotyped beliefs with the supposed characteristics for the job. And, in doing so, discriminates the candidate based on the apparent lack of adjustment between the job and the profile of the candidate.

The photo highlights a striking feature: the color of the skin, which allows the perceiver to receive specific information contained in the category. This additional information then becomes part of the basis for judgment, regardless of its relevance to the decision making. The results are consistent with the discussions proposed by Ruffle and Shtudiner (2011) and Little and Robert (2012) on evidence linking physical appearance to staffing and professional success.

It is important to note that the evaluation pattern for the photos in the résumés for the position of typist did not show significance in the evaluated items. It should be noted that the results show a tendency towards a candidate profile that is less white. It is possible to discuss how skin color and other physical attributes would be of little importance to a typing 
professional. Job ads for typists do not include appearance as a criterion, as this job does not require contact with outside public or clients.

It should be emphasized that the participants, in making the choice of résumés, should present the reasons that led to the decision. The contents identified in these justifications for the selection for the seller position were divided into the following themes: academic background; professional experience; competence.

\section{COMPARISON BETWEEN THE JUDGMENT OF STUDENTS AND HUMAN RESOURCES PROFESSIONALS}

The following hypothesis assumed that, unlike the students' choice pattern, HR professionals tend to make choices by acquiescing to the racist norm. The labor market pressures those responsible for selecting personnel in their organizations to choose a candidate to fill a position, influenced by racial stereotypes. (SHAHANI-DENNING, 2003).

When the participants' choices are analyzed according to their skin color, the results show another discrepancy in the assessment made by professionals and students. Professionals tend to choose candidates with a lighter skin tone for the seller position. These participants show preference for résumés with photos that are closer to the prototypical images of blacks for the typist position. Students, on the other hand, show less tendency toward a selection based on skin color.

There was no moderating effect of racial affiliation $\left(F_{(1)}=0.674, p=0.983\right)$, nor of the sex of the professional participants $\left(F_{(1)}=0.423, p=0.524\right)$ in choosing the résumés with a photo for the seller. For the typist function, similarly, these participants, according to gender $\left(F_{(1)}=0.99, p=0.757\right)$, do not differ in the judgments of the résumés. Professional experience, however, seems to determine the different pattern of choice for customer service positions and positions that do not require direct contact with the public/ client. The discrepancy in these results motivated a more refined analysis to evaluate these data. There is a tendency for professionals to choose candidates with a lighter skin color for the seller position $\left(\mathrm{M}=5.0, \mathrm{SD}=2.4 \mathrm{t}_{(41)}=2.9, \mathrm{p}<0.05\right)$, which is not manifested in relation to the evaluation of candidates for the position of typist $\left(M=4.2, S D=2.2, t_{(18)}\right.$ $=0.42, p=.68$ ). The students, however, despite choosing, in average, the candidates with lighter skin tone, presented a lower mean $(M=4.6, S D=2.62)$ for the seller position and higher for the typist $(M=5.0, S D=2.4)$. These results do not demonstrate statistical relevance for the evaluation of the seller's $\left(t_{(16)}=1.01 \mathrm{p}=.32\right)$ and typist's résumé $\left(\mathrm{t}_{(16)}=\right.$ $1.72, \mathrm{p}=.11$ ).

Racial belonging $\left(F_{(1)}=5,530, p<0.05\right)$ showed a significant influence on the results of professionals (Figure 1 ). Professionals who declared themselves brown and white tended to choose résumés with photographic images depicting a fairer complexion $(\mathrm{M}=$ $4.9, \mathrm{SD}=2.7$ ). On the other hand, the résumés with prototypical photos of candidates with a darker skin tone were more often chosen by participants who see themselves as blacks $(\mathrm{M}=2.7, \mathrm{SD}=1.21)$.

The choice of professionals for this position, even though they do not have direct contact with the public, is influenced by the perception of the candidates' photo. The discrepancy between the means of the groups of participants has an effect when taking into 
account the skin color of the professionals. Professionals who have not declared themselves to be black maintain a choice based on the appearance of candidates even in a position that does not require contact with customers.

It is noted in-group favoritism in this choice, in accordance with studies on social identity. Lima and Vala (2004) and Vala (1997) discuss how the activation of an identity dimension, when intergroup differentiation proves to be salient, triggers more positive endogroup evaluations.

Figure 1 - Graph of the 95\% confidence intervals of the averages of choices by skin color of sellers and typists, depending on the professional category and color of the participant

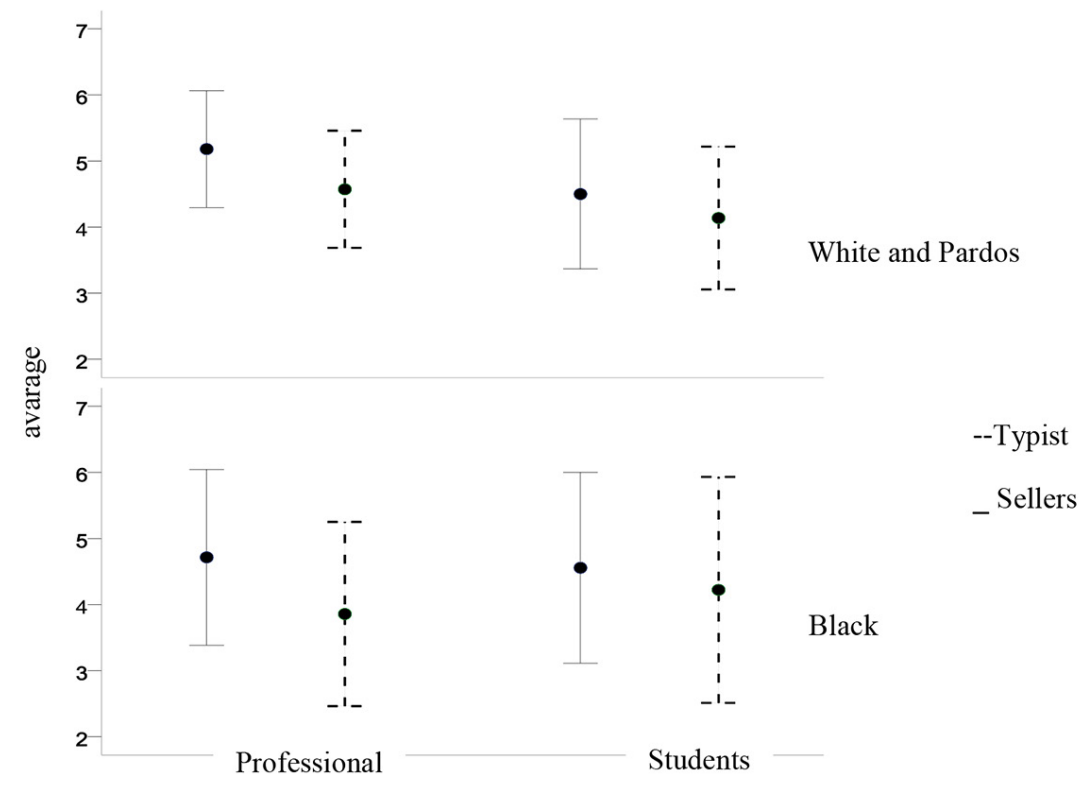

Source: Research Data.

Students who participated in the survey in the photo condition show the same pattern of results when choosing a seller. The pattern of choice of these participants is not different between those who declare blacks, browns or whites $\left(F_{(1)}=0.354, p=561\right)$ and between male and female participants $\left(F_{(1)}=0.004, p=0.527\right)$. In the selection process for the typist position, the results show that $\operatorname{sex}\left(F_{(1)}=0.93, p=0.765\right)$ and racial identification $\left(F_{(1)}=0.23, p=0.370\right)$ do not influence the responses of participants either.

Professionals, in the no-photo condition, faced with the scale of motivation to control prejudice, showed a tendency toward internal control of prejudiced attitudes $\left(\mathrm{M}_{\mathrm{IC}}=\right.$ 4.07, $\left.\mathrm{SD}=0.65, \mathrm{t}_{(22)}=7.94, \mathrm{p}<0.05\right)\left(\mathrm{M}_{\mathrm{EC}}=2.2, \mathrm{SD}=0.73, \mathrm{t}_{(1)}=-5.12, \mathrm{p}<0.05\right)$. The results showed the same pattern in the condition that the résumés were evaluated with a photo $\left.\left(\mathrm{M}_{\mathrm{IC}}=4.10, \mathrm{SD}=0.75, \mathrm{t}_{(18)}=6.38, \mathrm{p}<0.05\right)=0.73, \mathrm{t}_{(1)}=-5.46, \mathrm{p}<0.05\right)$.

With the scale of motivation, students and professionals show greater internal control of prejudice in the condition with photo $\left(\mathrm{M}_{1 \mathrm{C}}=4.0, \mathrm{SD}=0.81, \mathrm{t}_{(14)}=4.91, \mathrm{p}\right.$ $<0.05),\left(\mathrm{M}_{\mathrm{EC}}=2.1, \mathrm{SD}=0.66, \mathrm{t}_{(1)}=-5.07, \mathrm{p}<0.05\right)$ and no photo $\left(\mathrm{M}_{\mathrm{IC}}=4.3, \mathrm{SD}=\right.$ 
$\left.0.37, \mathrm{t}_{(16)}=14.374, \mathrm{p}<0.05\right)\left(\mathrm{M}_{\mathrm{EC}}=2.4, \mathrm{SD}=0.85, \mathrm{t}_{(16)}=-2.86, \mathrm{p}<0.05\right)$. Such $\mathrm{a}$ finding reveals how external standards and social norms would have less influence on the expression of prejudice than personal beliefs among participants.

The dynamics of race relations in the contemporary world translates into the attempt of people to appear to be less prejudiced. The studies of Plant and Devine (1998) show how the external and internal motivations for controlling prejudice are two different motivational forms, but which are interrelated in the attitudinal structure of an individual. Gouveia et al. (2006) indicate that people who are internally motivated to respond without being prejudiced tend to be less prejudiced than those who are motivated externally. The participants respond without being prejudiced, driven more by personal interests (motivated internally) than by the characteristics of the social context and pressures to agree to non-biased norms (externally motivated). The internal motivation to respond without being prejudiced presupposes that people tend to position themselves on the basis of internal and personal standards.

The professionals in the no-photo condition present the same mean pattern in the racial privilege factor $\left(M_{R P}=3.9, S D=0.72, t_{(22)}=6.43, p<0.05\right)$ that the participants in the condition with photo $\left(\mathrm{M}_{\mathrm{RP}}=4.0, \mathrm{SD}=0.72, \mathrm{t}_{(18)}=9.28, \mathrm{p}<0.05\right)$. The mean of the students for the racial privilege factor, in the no-photo condition $\left(\mathrm{M}_{\mathrm{RP}}=3.7, \mathrm{SD}=0.42\right.$, $\left.t_{(14)}=6.86, p<0.05\right)$ and with photo $\left(M_{R P}=3.9, S D=0.63, t_{(16)}=5.73, p<0.05\right)$ is also close to the professionals'. Participants demonstrate agreement with the existence of privilege based on skin color that negatively affect blacks in their professional insertion. Racial privilege is a factor composed of six items (6) extracted from the "racial blindness" scale of Neville et al. (2000). It refers to an attitudinal structure that is characterized by a "blindness" to the existence of privileges and advantages for the white population to the detriment of the other racial groups.

In Brazil, racism determines unequal relations, despite racial mixing and fluidity between groups (TELLES, 2003). Racism represents an organized system of exclusion that structures itself on the basis of social disadvantages and limited opportunities for a group because of its racial belonging (DOVIDIO; GAERTNER; KAWAKAMI, 2013). In this context, racial privilege is revealed through socioeconomic injustices among racial groups, especially in the labor market. The data of survival conditions disclose the precariousness to which the black population is subjected, in opposition to the benefits generated to the white population (SABINO, 2006). The exclusion or insignificant representation of blacks in prestigious positions reiterates the discussion that social structures determine rights in terms of racial belonging. (SMITH; BRIEF; COLELLA, 2013).

In our study, the professionals, in the no-photo condition, presented the same pattern of mean in the Labor Market Racism Inventory $\left(\mathrm{M}_{\mathbb{I R}}=0.7, \mathrm{SD}=0.23, \mathrm{t}_{(22)}=\right.$ $-45,916, p<0.05)$ that the participants in the photo condition $\left(M_{\mathbb{R}}=0.7, S D=0.23, t_{(18)}\right.$ $=-45.916, p<0.05)$. The response of students to the Inventory of Racism in the Labor Market, however, points to another direction of the value presented by professionals. On average, in the no-photo condition they agree less that racial membership affects discrimination in insertion on the labor market or career advancement $\left(\mathrm{M}_{\mathbb{R}}=0.5, \mathrm{SD}=0.26, \mathrm{t}_{(14)}\right.$ $=-57.601, p<0.05)$, as well as in the condition with photo $\left(M_{\mathbb{I R}}=0.5, S D=0.28, t_{(1)}\right.$ $=-58.466, p<0.05)$. The comparison between the means of the groups showed statistical 
significance in relation to the condition without photo $\left(\mathrm{F}_{(1)}=8.53, \mathrm{df}=1, \mathrm{p}<.05\right)$ and with photo $\left(F_{(1)}=6.78,1, p<.05\right)$.

The job market places pressure on those in charge of recruiting staff in their organizations to fill positions according to a candidate profile which has a pre-defined physical appearance. The logic that defines skin color as a reference for this pattern of choice translates how racism defines entry, permanence and growth of people in the business environment. In this sense, the attractiveness factor in decision-making and its implications for the discrimination in the labor market (PEREIRA, 2015; SHAHANI-DENNING, 2003; AGTHE et al., 2014) is influenced by stereotyped beliefs and expectations of behavior in relation to the attractiveness of the target (LANGLOIS et al., 2000). Professionals, whether or not they adhere to the thesis on racism, seem to be more in favor of the racist standard by choosing candidates with a fairer complexion.

In this study, it was verified that beliefs about Racism in the labor market did not influence the results in the choices for seller $\left(F_{(1)}=3.03, p=0.86\right)$ and typist $\left(F_{(1)}=0.802\right.$, $p=0.591)$. The judgment of candidates' résumés did not depend on the perceptions about racial inequalities in employment.

Modern racism is revealed in indirect ways and many times imprecise manners (LIMA; VALA; 2004; NUNES, 2010), and also in some other direct and declared ways of racial hierarchization (ZÁRATE, 2009). The laws which prohibit racism tend to inhibit its manifestation. Lima and Vala (2004) state that, in Brazil, there is a "Cordial Racism" that coexists in a harmonious way with the anti-racist norm, which makes this type of racism much more difficult to detect and fight. It is in this context that we can situate the results of judgement on good appearance in our study.

\section{JUDGMENT OF GOOD APPEARANCE}

The skin color of the participant did not influence the results, as there is no difference between the black, brown and white participants on the definitions among the criteria on the suitable appearance for a job vacancy. The sex of the participants has the same pattern of racial belonging, having no effect on the answers on the items $\left(F_{(1)}=0.327, p=\right.$ 0.569) $\left(F_{(1)}=0.223, p=0.638\right)$.

Table 1 - Average indicators of good appearance between professionals and students

\begin{tabular}{lcc}
\hline Indicator/participants & Professional & Student \\
\hline Hygiene & $\mathrm{M}=2,79 ; \mathrm{SD}=0,42$ & $\mathrm{M}=2,97 ; \mathrm{SD}=0,18$ \\
Attire & $\mathrm{M}=2,50 ; \mathrm{SD}=0,51$ & $\mathrm{M}=2,41 ; \mathrm{SD}=0,56$ \\
Hair & $\mathrm{M}=1,74 ; \mathrm{SD}=1,01$ & $\mathrm{M}=1,60 ; \mathrm{SD}=0,87$ \\
Skin color & $\mathrm{M}=0,62 ; \mathrm{SD}=1,06$ & $\mathrm{M}=0,19 ; \mathrm{SD}=0,47$ \\
\hline
\end{tabular}

Source: Research data.

There is a significant difference in relation to the four criteria (skin color, hygiene, attire, hair). The hypothesis that skin color would have a lower frequency as a defining 
criterion was corroborated. The participants chose hygiene as a more present element in the evaluation of a candidate, rejecting the hypothesis that the attire would present a higher frequency among the participants (Table 1).

The use of good appearance is an everyday practice in decision making in personnel selection. It is assumed that certain positions should be filled only by candidates with characteristics that would transcend professional skills. Regardless of professional background, this would be a key criterion for recruiting a candidate (LITTLE; ROBERTS, 2012).

There is a discussion in the literature that associates the requirement of a particular appearance for certain jobs to the subtle and concealed form of Brazilian racism that was structured on the basis of stereotyped beliefs and negative representations of the black population or the denial of positive attributes (SILVÉRIO, 2002; DAMASCENO, 2011). Such an argument is reinforced in the studies of Damasceno (2011) who identified job advertisements from the 1930s, associating the requirement of good appearance to the racial group of the candidate. It should be clarified that this judgment is recurrent for vacancies that require direct contact with the client, such as salespeople and executive secretary (PAIM, 2005).

The results demonstrate that, for the participants, the skin color would have a lower influence than the other items to define good appearance. It is possible to analyze this result based on two considerations: the participants' attempt not to demonstrate racial prejudice and the valorization of professional competence instead of less objective criterion for the selection of a candidate.

The scientific literature refers to the implicit forms of racism that present themselves in the face of norms that have prevented the manifestation of unequal attitudes and beliefs. People, in an attempt to respond without being prejudiced, are guided by two forms of independent motivations: external and internal (PLANT; DEVINE, 1998; GOUVEIA et al., 2006). Internal motivations are guided by personal interests, and external motivations are driven by social contingencies. In the studies by Plant and Devine (1998), participants motivated by external pressure showed differences in their endorsement of racial stereotypes as a function of providing responses in private or in public. They, it seems, strategically alter their responses in public to avoid revealing their true prejudices. In the absence of outside observers, they responded with strong support of the stereotype. Those who were internally motivated, regardless of their external motivation level, as well as those who reported not being particularly motivated to respond without showing prejudice, showed little difference in the expression of stereotypes whether public or not. The authors discuss the importance of considering the joint influence of internal and external motivation to respond without showing prejudice when evaluating the probable situational impact of the responses.

Gouveia et al. (2006) validated a scale of motivations to respond without prejudice to blacks in Brazil. Such study becomes reference in this research by its pioneering in the use of this scale. The internal motivation factor to respond without prejudice has some items like "According to my values, it is right to use stereotypes in relation to blacks" and "I try to act in a non-prejudiced way because it is important to me". The external motivation factor to respond without prejudice presents items such as "I try not to present prejudice to avoid disapproval" and "because of norms do not show prejudice against blacks". 
Participants may seek control of their prejudiced attitudes in their judgment of the factors that determine the ideal look for job openings. However, there is no interaction between the participants' responses on the motivation scale to control prejudice and the evaluation of good appearance, both among students $\left(F_{(1)}=0.282, p=0.602\right)$ and among professionals $\left(F_{(1)}=0.037, p=0.850\right)$.

It is necessary to discuss social norms to understand the reasons for controlling biased attitudes, the forms of internalization and the social pressures that give rise to motivations to respond without prejudice. Anti-racist norms seek effective control over the behavior of individuals to prevent social expectations and judgments from negative stereotypes that promote social exclusion. Lima et al. (2006) investigated the effect of social norms on automatic prejudice against blacks, based on two normative contexts (egalitarian and meritocratic). The results indicated that prejudice is influenced by situational factors represented by response contexts. The context of competition has made people more prejudiced. The context of solidarity equality inhibited prejudice against blacks. The authors state that racism in Brazilian society manifests itself violently by finding an appropriate normative context that can justify or disguise its practices of exclusion against social minorities. Current racism combines flagrant and subtle forms of expression that circumvent the anti-racist norm in democratic societies (LIMA et al, 2006; PEREIRA; VALA, 2011). The present, more open forms of expression of racism allow us to discuss how racism is a complex phenomenon that articulates subtle and direct hierarchies.

Research on racism in the labor market can be categorized in three perspectives, individual, group and systemic (DIPBOYE; COLELLA, 2003). Individual perspective, such as the theory of social categorization, includes discrimination based on stereotyped beliefs and prejudices (DOVIDIO; HEBL, 2003). Gelfand et al. (2003) found that the relevant research on group relations focuses on problems involving social categories and disadvantages based on shared or assigned characteristics. Finally, systemic theories refer to approaches that view organization as an open system in which broader aspects such as culture, leadership, human resource systems and organizational climate can contribute to or mitigate discrimination. These aspects would be mediated by cognitive processes and interpersonal relationships and influenced by the socio-cultural environment (THOMAS; CHROBOT-MASON, 2003). The research on diversity in organizations is an example of systemic studies (ROSA, 2014; TORRES; PÉREZ-NEBRA, 2004), mainly as a strategy for identifying and evaluating business practices for inclusion, development and management of human resources performance.

Dipboye and Colella (2003) propose a multilevel model of analysis of discrimination in the labor market, articulating these perspectives of analysis. A study of the judgment of good looks in this sense requires a complex articulation of organizational processes at all levels, which are articulated as determinants of the obstacles that the black population faces in accessing job openings

\section{FINAL CONSIDERATIONS}

The objective of this investigation was to evaluate the effect of race on the judgment of candidates in personnel selection. The phenomenon of good appearance is present in the discourse of recruiters and candidates and is criticized for its association with racist beliefs 
and representations. The job ads in the 1980s presented this requirement in staff selection. The behavior of recruiters and candidates was openly and explicitly guided by this criterion. Recruiters maintained an explicitly discriminatory process, while the candidates conformed to that standard. This criterion is no longer visible in the ads, but is still present in HR practices, revealing a subtle form of Brazilian racism, which was structured based on stereotyped beliefs and negative representations of the black population or denial of positive attributes. To reach the proposed objective, a simulation of the selection of personnel was conducted, with the participation of human resources professionals and undergraduate students.

The results showed that the inclusion of photos has an effect on the evaluation of résumés in the case of professionals. Unlike students, professionals chose candidates who had a lighter skin tone when selecting personnel for positions that demanded good appearance. Résumés with prototypical pictures of blacks were more likely to be excluded in the selection processes than résumés with prototypical images of whites.

The hypothesis that the color of the skin would show a lower frequency as criterion that defines good appearance was corroborated. Participants chose hygiene as a more present element in the evaluation of a candidate. The results demonstrate that, for the participants, when defining good appearance, skin color would have a smaller influence when compared to the other items used to define good appearance. It is possible to analyze this result based on two considerations: the participants' attempt not to demonstrate racial prejudice and the valorization of professional competence instead of less objective criterion for the selection of a candidate.

In an Organization that does not value competence in staff selection, what counts is the subtle or explicit racist beliefs and representations that tend to guide the behavior of the recruiter and the Personnel Management policy. On the other hand, the choices in a selection process must follow the premise that the differences between people transform the organizational environment into an innovative, creative and productive space.

\section{REFERENCES}

AGENTES EDUCADORES. Termo "boa aparência" proibido em anúncios de emprego. Avaliable on: <http://www.agenteseducadores.com.br/termo-boa-aparencia-proibido-em-anuncios-de-emprego/> . Acessed on 18/05/2016.

AGTHE, M. et al. Looking up versus looking down: attractiveness-based organizational biases are moderated by social comparison direction Journal of Applied Social Psychology, v. 44, p. 40-45, 2014.

AUGOUSTINOS, M; WALKER, I. Social cognition. An integrated introduction. London: Sage Publications, 2006.

BAR-TAL, D. Formation and Change of Ethnic and national Stereotypes: An integrative model. Int. J. Intercultural, v. 4, p. 491-523, 1997.

BENDICK JR, M; NUNES, A. P. Developing the Research Basis for Controlling Bias in Hiring. Journal of Social Issues, v. 68, n. 2, pp. 238-262, 2012. 
BIERNAT, M. Stereotypes and Shifting Standards. In: NELSON, T. D (ed.). Handbook of prejudice, stereotyping, and discrimination. New York: Psychology. pp. 137-149, 2009.

BIERNAT, M.; FUEGEN, K.; KOBRYNOWICZ, D. Shifting Standards and the Inference of Incompetence: effects of formal and informal evaluation tools. Personality and Social Psychology Bulletin, v. 36, n. 7, pp. 855-868, 2010.

BROWN, R. Prejudice: Its Social Psychology. 2 ed. Oxford: Blackwell, 2010.

BROWN-IANNUZZI, J. L.; PAYNE, B. K., TRAWALTER, S. Narrow imaginations: How imagining ideal employees can increase racial bias. Group Processes \& Intergroup Relations, v. 16, n. 6 , pp. 661-670, 2012.

CAMINO, L. et al. A Face Oculta do Racismo no Brasil: uma análise psicossociológica. Revista Psicologia Política, v.1, n. 1, pp. 13-36, 2001.

CASTRO, M. G.; ABRAMOVAY, M. Jovens em situação de pobreza, vulnerabilidades sociais e violências. Cadernos de Pesquisa, n. 116, pp. 143-176, 2002.

CHICO SANTANA E INFOCOM. Emissora de TV exige foto de corpo inteiro para selecionar repórter. Brasilia, 12 de junho de 2012. Available on: < http://chicosantannaeainfocom. blogspot.com/2012/06/emissora-de-tv-exige-foto-de-corpo.html>. Acessed on 18.04.2015.

COTTON, J. L.; GILBERT M. Racial. Prejudice in Hiring Practices. Available on: $<$ https://vault. hanover.edu/ altermattw/courses/344/papers/2007/Cotton,Gilbert.pdf>. Acessed on 25/09/2016.

LEIS MUNICIPAIS. Salvador, 07/04/2010. Leis municipais. Available on: $<$ https://leismunicipais.com.br/a/ba/s/salvador/lei-ordinaria/1998/542/5420/lei-ordinaria-n-5420-1998-dispoe-sobre-a-proibicao-da-subjetiva-expressao-boa-aparencia-ou-equivalente-em-anuncios-que-objetivem-selecionar-candidatos-para-o-preenchimento-de-vagas-em-quaisquer-estabelecimentos-empresas-ou-similares-e-da-outras-providencias $>$. Acessed on 18.05.2016.

DAMASCENO, C. Segredos da boa aparência: da "cor" à "boa aparência" no mundo do trabalho carioca (1930 - 1950). Rio de Janeiro: EDUURRF, 2011.

DAVISON, H. K.; BURKE, M. J. Sex Discrimination in Simulated Employment Contexts: A Meta-analytic Investigation. Journal of Vocational Behavior, v. 56, pp. 225-248, 2000.

DOVIDIO, J.F.; HEBL, M. R. Discrimination at the Level of the Individual: Cognitive and Affective Factors. In.: DIPBOYE, R. L.; COLELLA, A. (eds.). Discrimination at Work; The Psychological and Organizational Bases. New Jersey: Lawrence Erlbaum Associates, Inc., Publishers, p. 537, 2005.

DOVIDIO, J.F.; GAERTNER, S. L.; KAWAKAMI, K. Racism. In: DOVIDIO, J. F. et al (eds.). The sage handbook of prejudice, stereotyping and discrimination. London: Sage, p. 606, 2013.

FIGUEIREDO, A. Beleza pura: símbolos e economia ao redor do cabelo do negro. 1994. Monografia (Graduação em Ciências Sociais) - Faculdade de Filosofia e Ciências Sociais, Universidade Federal da Bahia, Salvador, 1994. 
FRYBERG, S. A.; TOWNSEND, S. S. M. The Psychology of Invisibility. In: ADAMS, G. et al. (eds.). Commemorating Brown: The Social Psychology of Racism and Discrimination., Washington, DC: American Psychological Association. 2008.

GOMES, C. A.; BRAGA, H. E.; VIEIRA, W. M. Trabalho e educação: que indicam os anúncios classificados? Caderno CRH, v. 21, n. 52, p. 131-144, 2008.

GOUVEIA, V. V. et al. Correlatos Valorativos das Motivações para Responder sem Preconceito. Psicologia: Reflexão e Crítica, v. 19, n. 3, p. 422-432, 2006.

GUIMARÃES, A. S. Como trabalhar com "raça" em sociologia. Educação e Pesquisa, v. 29, n. 1, p. 93-107, 2003.

Preconceito de cor e racismo no Brasil. Revista de Antropologia USP, v. 47, n. 1, p. 9-43, 2004.

HARRISON M. S.; THOMAS, K. M. The Hidden Prejudice in Selection: A Research Investigation on Skin Color Bias. Journal of Applied Social Psychology, v. 39, n. 1, p. 134-168, 2009.

HOSODA, M.; STONE, D. L.; STONE-ROMERO, E. F. The Interactive Effects of Race, Gender, and Job Type on Job Suitability Ratings and Selection Decisions. Journal of Applied Social Psychology, v. 33, n. 1, p. 145-178, 2003.

JUSSIM, L. et al. The Unbearable Accuracy of Stereotypes In: NELSON, T. D. (ed.). Handbook of prejudice, stereotyping, and discrimination. New York: Psychology Press, 2009.

LANGLOIS, J. et al. Maxims or myths of beauty? A meta-analytic and theoretical review. Psychological Bulletin, v. 126, p. 390-423, 2000.

LIMA, M. E. O.; VALA, J. As novas formas de expressão do preconceito e do racismo. Estudos de Psicologia, v. 9, n. 3, p. 401-411, 2004.

LIMA, M. E. O. A cor do sucesso: efeitos da performance social e econômica no branqueamento e na infra-humanização dos negros no Brasil. Psicologia USP, v. 16, n. 3, p. 143-165, 2005.

LIMA, M. E. O. et al. Normas sociais e preconceito: o impacto da igualdade e da competição no preconceito automático contra os negros. Psicologia: Reflexão e Crítica, v. 19, n. 2, p. 309-319, 2006.

LITTLE, A. C.; ROBERTS, S.C. Evolution, appearance, and occupational success. Evolutionary Psychology, v. 10, n. 5, p. 782-801, 2012

MAZON, L.; TREVIZAN, M.A. Recrutamento e seleção de recursos humanos em um hospital psiquiátrico de um município paulista. Rev. latino-am. enfermagem, v. 8, n. 4, p. 81-87, 2000.

MENDES, A.I.F., ARRAIS, K.C.; FUKUSIMA, S.S. Faces Prototípicas Provenientes de Amostras Populacionais de uma Região Brasileira. Psicologia: Reflexão e Crítica, v. 22, n. 2, p. 261-268, 2009.

MOURA, R. G.; LOPES, P.L. O Preconceito e a Discriminação de Transgêneros no Processo de Recrutamento e Seleção de Pessoal: uma Revisão Bibliográfica. In: SEGET - SIMPÓSIO 
DE EXCELÊNCIA EM GESTÃO E TECNOLOGIA, 15., Resende, RJ, 2014. Available on: <http://www.aedb.br/seget/artigos2014.php?pag=186>. Acessed on 12/09/2016.

NEVILLE, H. A. et al. Construction and Initial Validation of the Color-Blind Racial Attitudes Scale (CoBRAS). Journal of Counseling Psychology, v. 47, n. 1, p. 59-70, 2000.

NUNES, S. S. Racismo contra negros: um estudo sobre o preconceito sutil. 2010. Tese (Doutorado), Instituto de Psicologia, Universidade de São Paulo, 2010.

PAGER, D.; WESTERN, B. Race at Work: Realities Of Race And Criminal Record in the NYC Job Market. Conference Race At Work - Realities of Race and Criminal. 2005 Available on: $<$ https://scholar.harvard.edu/files/pager/files/race_at_work.pdf > . Acessed on 21/09/2016.

PAGER, D.; WESTERN, B. Identifying Discrimination at Work: the use of field experiments. Soc Issues, v. 68, n. 2, p. 221-237, 2012.

PAGER, D.; WESTERN, B.; BONIKOWSKI, B. Discrimination in a Low-Wage Labor Market: A Field Experiment. American Sociological Review, v. 74, p. 777-799, 2009.

PAIM, A. S. Aparência física, estereótipos e inserção profissional: um estudo sobre a profissão de secretariado executivo segundo a percepção das estudantes de secretariado. 2005. Dissertação (Mestrado), Universidade Federal da Bahia, 2005. Available on: <https:// pospsi.ufba.br/sites/pospsi.ufba.br/files/altair_paim.pdf>. Acessed on 12/10/2016.

. Pele negra sem máscaras brancas: o julgamento da boa aparência em seleção de pessoal. 2016. Tese (Doutorado), Universidade Federal da Bahia, 2016. Available on: <https://pospsi.ufba.br/sites/pospsi.ufba.br/files/altair_paim_tese.pdf $>$. Acessed on 12/10/2017.

PEREIRA, C.; VALA, J. A legitimação da discriminação em diferentes contextos normativos. In: TECHIO, E. M.; LIMA, M. E. O. (eds.). Cultura e produção das diferenças: estereótipos e preconceito no Brasil. Espanha e Portugal. Brasília: TechnoPolitik, 2011, p. 363-404.

PEREIRA, M. E. Psicologia Social dos Estereótipos. São Paulo: Edusp, 2002.

Enfrentando preconceitos e estereótipos. Na escola, no trabalho, nas ruas e os que sobrevivem em cada um de nós. 2015. Available on: <https://estereotipos.net/>. Acessed on $12 / 11 / 2016$.

PLANT, E. A.; DEVINE, P. G. Internal and external motivation to respond without prejudice. Journal of Personality and Social Psychology, n. 75, p. 811-832. 1998.

NATIONAL HEALTH COUNCIL. Resolution 466/2012. Approve the following guidelines and standards regulating researches involving human beings. Available on: <http://conselho. saude.gov.br/resolucoes/2012/466_english.pdf > . Acessed on 19.09.2018.

ROOTH, D. Automatic associations and discrimination in hiring: Real world evidence. Labour Economics, v. 17, p. 523-534, 2010.

RUFFLE, B. J.; SHTUDINER, Z. Recognition bias and the physical attractiveness stereotype. Scandinavian Journal of Psychology, v. 2012, n. 53, p. 239-246, 2011.

SABINO, G. F. T. Racismo: o negro e as condições de sua inserção no mercado de trabalho brasileiro no final da década de 90. Revista Urutágua (Online), v. 1, p. 06, 2006. 
SALGUEIRO, J. E. Contribuição para o estudo do preconceito em contexto organizacional. In: FARINA, A. A. S. et al. Temas Contemporâneos em Psicologia Organizacional e do Trabalho. São Paulo: Expressão e Arte, 2009.

SANTOS, W. S. et al. Escala de racismo moderno: adaptação ao contexto brasileiro. Psicologia em Estudo, v. 11, n. 3, p. 637-645, 2006.

SHAHANI-DENNING, C. Physical attractiveness bias in hiring: what is beautiful is good. Hofstra Horizons. Available on: <https://www.hofstra.edu/pdf/orsp_shahani-denning_ spring03.pdf $>$. Acessed on 20.09.2018.

SMITH, A. N.; BRIEF, A. P.; COLELLA, A. Bia in Organizations. In: DOVIDIO, J. F. et al. (eds.). The sage handbook of prejudice, stereotyping and discrimination. London: Sage, 2013.

TELLES, E. Racismo à brasileira: uma nova perspectiva sociológica. Rio de Janeiro: Relume-dumará, 2003.

UHLMANN, E. L.; SILBERZAHN, R. Conformity under uncertainty: reliance on gender stereotypes in online hiring decisions. Behavioral and Brain Sciences, v. 37, n. 1, p. 103-104, 2014. doi: 10.1017/S0140525X13001921.

VALA, J. Representações sociais e percepções intergrupais. Análise Social, v. 32, p. 7-29, 1997.

ZÁRATE, M. A. Racism in the 21st Century In: NELSON, T. D (ed.). Handbook of prejudice, stereotyping, and discrimination. New York: Psychology Press, p. 6082009.

Data de submissão: 28/09/2017.

Data de aprovação: 24/07/2018.

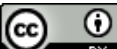

Creative Commons Atribuição 4.0 Internacional

Note: you can find this paper in Portuguese at http://www.revistaoes.ufba.br. 